\title{
Contamination, Prevention and Control of Listeria monocytogenes in Food Processing and Food Service Environments
}

\author{
Frederick Tawi Tabit
}

Additional information is available at the end of the chapter

http://dx.doi.org/10.5772/intechopen.76132

\begin{abstract}
This chapter reviews issues related to the occurrence and growth of Listeria monocytogenes in food processing and food service environments. L. monocytogenes is a food-borne pathogen with the capacity to contaminate raw or minimally processed foods such as chilled ready-to-eat (RTE) foods. The consumption of food contaminated with L. monocytogenes can result in a disease known as listeriosis among vulnerable groups of people such as pregnant women and fetuses, newborns, adults between the ages of 65 and 75, and people with weakened immune systems. L. monocytogenes is ubiquitous and has been isolated from soil, vegetation, sewage, water, animal feed, fresh and frozen meat including poultry, slaughterhouse wastes and the feces of healthy animals and humans. The bacterium is both acid tolerant and salt tolerant. It is able to grow at refrigerator temperature, and is therefore often associated with the consumption of raw or minimally processed and often chilled RTE foods. L. monocytogenes is able to form biofilms on food processing and preparation surfaces, which protects it from antimicrobial action. Continuous education of vulnerable groups regarding food safety will increase their awareness of the importance of practicing safer food handling practices such as hand washing and safe storage of RTE foods as a means to prevent listeriosis.
\end{abstract}

Keywords: Listeria monocytogenes, ready to eat food, listeriosis, food safety

\section{Introduction}

Listeria monocytogenes is a bacterium which is ubiquitous in nature, and occurs frequently in food processing and handling environments [1]. The consumption of food contaminated with 
L. monocytogenes can result in a disease known as listeriosis, to which pregnant women and their newborns, adults aged 65 or older, and people with weakened immune systems are particularly vulnerable [2]. In healthy adults, listeriosis is most likely to manifest as mild gastroenteritis. However, in some instances it can result in more severe symptoms, which can lead to life-threatening illnesses such as endocarditis, encephalitis or meningitis, and severe sepsis [3].

Inadequate food hygiene practices during food preparation are primarily responsible for the propagation of the bacterium and contamination of ready-to-eat (RTE) foods (Table 1) during processing, distribution and handling [4]. Small to medium-sized enterprises (SMEs) are more likely to experience L. monocytogenes outbreaks than renowned large-scale food processing enterprises owing to differences in the implementation of food safety measures [5].

RTE foods, which are often stored at low temperatures, are the type most susceptible to contamination with L. monocytogenes since the bacterium is psychrotrophic and possesses the ability to survive and grow in the presence of many food preservation systems, such as low $\mathrm{pH}$ and high salt concentrations [6]. The contamination of minimally processed fruit and vegetable products with L. monocytogenes is often a concern, considering that these foods, which are attractive to consumers, are often not subjected to lethal treatments during processing to inactivate potential pathogens [7]. Moreover, the manner in which RTE vegetables are sliced can affect the survival of Listeria and the effectiveness of decontamination procedures in the finished products. Hand tearing or manual slicing with a razor blade reduced the survival and growth of E. coli and L. innocua, probably because of less damage to the vegetable tissues and minimal leakage of nutrients from damaged plant tissues [8].

\begin{tabular}{lll}
\hline Year & Foodstuff implicated & Country of outbreak \\
\hline 2017 & Creamy, soft, raw-milk cheeses [2] & USA \\
2016 & Frozen vegetables [62] & USA USA \\
2016 & Raw milk chocolate milk products [63] & USA \\
2016 & Packaged salad [64] & USA \\
2015 & Soft cheese [65] & \\
2015 & Ice cream [66] & USA \\
2014 & Commercially produced, pre-packaged caramel apples [67] & USA \\
2014 & Mung bean sprouts [68] & USA \\
2014 & Soft cheese [69] & USA \\
2014 & Cheese products [70] & South Africa \\
$2017-2017$ & Various food products [71] & Australia \\
2017 & Not determined [72] & 28 EU/EEA countries \\
2014 & Various food products [73] & \\
\hline
\end{tabular}

CDC: Centre for Disease Control, NICD: National Institute for Communicable Diseases, ECDC: European Centre for Disease Prevention and Control, USA: United States of America, EU: European Union, EEA: European Economic Area.

Table 1. Some records of global Listeria outbreaks between 2014 and 2017. 
L. monocytogenes has the ability to attach itself to food preparation contact surfaces and grow to form protective biofilms, which generally protect the bacterial cells from antimicrobial action during cleaning and sterilisation processes [9]. However, low concentrations $(<10 \mu \mathrm{g} / \mathrm{mL})$ of paenibacterin have been found to suppress the growth of L. monocytogenes within the biofilm matrix as well as to down-regulate the genes involved in biofilm formation [10]. Considering that L. monocytogenes is a food-borne pathogen of public interest [11], the objective of this paper is to review issues related to the occurrence and growth of L. monocytogenes in food processing and food service environments.

\section{Health and economic impacts of listeriosis}

Globally, billions of people are at risk every year and thousands die as a result of consuming unsafe food [12]. In the United States of America (USA), listeriosis has been identified as the third leading cause of death from food-borne illness, after non-typhoidal Salmonella and Toxoplasma gondii, despite its rarity [13]. In Africa, food-borne illness continues to be a major health threat, especially for vulnerable groups such as infants, pregnant women and their newborns as well as immune-compromised individuals such as elderly people and those with HIV/AIDS [14].

In humans, invasive listeriosis is characterized by septicemia, meningitis, and abortion in pregnant women [15]. Listeriosis in pregnant women can result in premature labor, stillbirth, abortion, and neonatal infection, with high neonatal mortality [16]. It should be noted that L. monocytogenes infection in healthy individuals does not necessarily result in invasive disease. The incubation period of listeria-related gastroenteritis can range from 1 to 24 days, but the average incubation period has been found to be less than 24 hours. After the incubation period, prominent symptoms will include fever, then diarrhea, arthralgia, myalgia, and headache. Other common symptoms are nausea, vomiting, abdominal pain and watery diarrhea. In healthy individuals, the illness tends to last between 1 and 3 days, with a very low rate of hospitalization [17].

Listeriosis may have an economic impact in the form of costs incurred by the government in funding health institutions to deal with the problem [18]. Other costs can take the form of legal costs emanating from lawsuits imposed on food production companies arising from illness and death due listeriosis [19].

\section{Ecology and growth conditions of Listeria monocytogenes in the food chain}

L. monocytogenes are ubiquitous bacteria that can be found in different environments such as soil and water, and especially in food-manufacturing environments [20]. Many Listeria species have been isolated from soil, vegetation, sewage, water, animal feed, fresh and frozen meat including poultry, slaughterhouse wastes and the feces of healthy animals, including humans [21]. Animals have been found to be carriers of L. monocytogenes, hence the contamination of foods of animal origin, such as meats and dairy products [22]. 
L. monocytogenes can survive a low $\mathrm{pH}$ of 5.5 through a phenomenon known as the acid tolerance response (ATR), which causes cells to be more resistant in adverse acidic conditions [23]. The bacterium, which is notable for its persistence in food-manufacturing environments, is relatively salt-tolerant and is able to grow at refrigerator temperature, and is therefore often associated with the consumption of raw or minimally processed and often chilled RTE foods (e.g., soft and semi-soft cheese and smoked fish products), which are consumed without further processing $[24,25]$.

\section{The occurrence of L. monocytogenes in the food processing environment}

L. monocytogenes is able to attach to food processing surfaces and multiply to form biofilms in inaccessible locations in processing facilities [9]. Biofilms protect the bacterium against antimicrobial action, enabling it to colonize food processing equipment, conveyor belts, pipes, floors and drainage systems and to persist for months or even years, cross-contaminating different surfaces in food processing plants [26]. The formation of biofilms on various food contact surfaces by L. monocytogenes makes it extremely difficult to control this pathogen effectively, especially in processing plants where inadequate cleaning has been carried out [27].

\section{The occurrence of L. monocytogenes in RTE foods and food contact surfaces in food service facilities}

RTE foods have gained considerable popularity in many developing and developed countries because of their perceived better flavor, affordability and accessibility [28]. However, numerous L. monocytogenes outbreaks have been associated with RTE foods [29]. The prevalence of L. monocytogenes in RTE food is a major concern relating to food safety because RTE foods are consumed without further processing (cooking) or washing at home (Table 2). It is for this reason that stringent microbiological guidelines need to be formulated and followed to ensure that processors produce RTE food that is safe [30]. Implicated RTE foods include RTE deli meats, raw milk and other raw milk dairy products (soft cheese) (Table 1). Between 1999 and 2011, 73\% of all food-borne outbreaks of listeriosis that occurred in the United Kingdom (UK) were attributed to the consumption of sandwiches [31].

The presence of L. monocytogenes in RTE food is attributed to contamination during production, distribution or storage [32]. L. monocytogenes contamination in various food factory environments has been reported at nearly all stages of processing ([5] and Rodrigues et al. [33]). When compared with other food-borne pathogens such as Staphylococcus aureus, E. coli 015:H7, and Salmonella and Shigella species, L. monocytogenes has been found to be most prevalent on food contact surfaces in food service establishments [34]. Owing to its ability to grow in contaminated food during storage at refrigeration temperature, L. monocytogenes has 


\begin{tabular}{ll}
\hline Food groups & Susceptible food products \\
\hline Meat & $\begin{array}{l}\text { Processed meat products such as ground beef, sausages, deli ham, beef hot dogs and meat- } \\
\text { related sandwich products (e.g., pork, beef) } \\
\text { Poultry }\end{array}$ \\
Fish & Cookessed chicken such as deli chicken, deli turkey, eggs, and related sandwich products \\
Dairy & Cheese, yogurt \\
Fruit and vegetables & $\begin{array}{l}\text { Cabbage, lettuce, cucumber, frozen green beans, peanut butter, vegetable salads, raw } \\
\text { sprouts, cantaloupe melon and related salad dishes }\end{array}$ \\
Cereal and baked & Pasta, cakes, pies, sausage rolls \\
products &
\end{tabular}

Table 2. Listeria in food: foods that are susceptible to contamination by Listeria monocytogenes [57, 74].

been found in raw and processed RTE foods that required low temperature storage [35]. The high volume of food products such as meat, vegetables, dairy products and fruits that pass through the cold chain in food service establishments could contribute to the high incidence of L. monocytogenes in RTE food and on food contact surfaces [34, 36].

Inadequate cleaning procedures and hygiene practices can promote the formation of biofilms on food contact surfaces in food service establishments, thereby increasing the chances of L. monocytogenes cross-contamination within food service facilities [37]. Because biofilms are able to resist most sanitisers and disinfectants used, cross-contamination by L. monocytogenes poses a serious food safety risk in food service establishments, including domestic kitchens [38]. The ease with which L. monocytogenes is able to adhere to food contact surfaces and form biofilms increases the likelihood of its persisting on food contact surfaces, and hence crosscontaminating the final food products [39, 40]. The presence of food debris on food contact surfaces encourages the formation of L. monocytogenes biofilms [41].

\section{The occurrence of L. monocytogenes on food contact surfaces in domestic kitchens}

Inadequate hygiene practices in domestic kitchens may contribute to the persistence of foodborne pathogens, thereby compromising the safety of foods produced there [42]. Home kitchens have been found to be a significant location where food-borne illnesses are acquired. A survey conducted in the domestic kitchens of consumers aged 60 and above in the UK indicated that a large number of foods in home refrigerators were beyond the use-by date and up to $66 \%$ of opened RTE foods had been stored beyond the recommended 2 days after opening [43]. A study of the occurrence of Listeria spp. on food contact surfaces in domestic kitchens in the Netherlands found high levels of L. monocytogenes on dish-cloths and in bathrooms, but low levels on kitchen sinks, washing-up brushes and refrigerators [44]. Many researchers have found high levels of L. monocytogenes on refrigerator surfaces in domestic kitchens [45]. 


\section{Legislation relating to the occurrence of Listeria monocytogenes in foods}

Most food legislation stipulates the microbial criteria for food-borne bacteria such as L. monocytogenes or their toxins and metabolites in specific foods. These criteria often prescribe the acceptable levels of these bacteria or their toxins in food products available on the market [46]. Most foods that support the growth of L. monocytogenes should be the focus of risk management efforts. Countries such as Germany, the Netherlands and France have set a tolerance level of 100 colony forming units (cfu) of L. monocytogenes per gram of food at the time of consumption while others, such as the USA and Italy, require a total absence of L. monocytogenes in $25 \mathrm{~g}$ of food [47]. The new criteria for L. monocytogenes in RTE food gazetted by Food Standards Australia-New Zealand on 31 July 2014 prescribe two sets of criteria for L. monocytogenes for application based on whether the growth of the bacterium does or does not occur inherently in a particular RTE food. These criteria include fewer than $100 \mathrm{cfu}$ of L. monocytogenes per gram of food in which the growth of L. monocytogenes is not likely to occur, and that L. monocytogenes should not be detected in $25 \mathrm{~g}$ of food in which the growth of L. monocytogenes is likely to occur [48].

The Food Safety Standard of Ireland has prescribed the following in relation to L. monocytogenes: L. monocytogenes should be absent in $25 \mathrm{~g}$ of RTE food destined for infant consumption or for serving as a special food for medical purposes in up to 10 collected food samples. Similarly, in the case of RTE foods that are able to support the growth of L. monocytogenes: L. monocytogenes should be absent in $25 \mathrm{~g}$ of RTE food following production or should not exceed $100 \mathrm{cfu}$ per gram of food placed on the market during its shelf life, in up to 5 collected food samples. Lastly, in the case of RTE foods that are not able to support the growth of L. monocytogenes: L. monocytogenes should not exceed $100 \mathrm{cfu}$ per gram of food placed on the market during its shelf life, in up to 5 collected food samples [49].

\section{Methods commonly used for the identification of $L$. monocytogenes in foods}

\subsection{Culture methods}

L. monocytogenes can be isolated from contaminated samples by subjecting them to pre-enrichment. This entails mixing samples with enrichment media such as Listeria Enrichment Broth (Sigma), after which the enrichment samples can be cultured on L. monocytogenes-specific agar plates such as Listeria Mono Differential Agar (Sigma). Isolation can be performed using various other media and procedures [50]. Thereafter, pure cultures of L. monocytogenes to be used for downstream identification and characterization analysis can be prepared by isolating individual colonies from agar plates [51]. The culture-based methods are often used in combination with immunoassay- or molecular PCR-based methods for accurate detection of L. monocytogenes in food samples [52].

\subsection{Immunoassay}

During immunoassay, monoclonal antibodies specific to L. monocytogenes can be incorporated into various techniques for identification. Immunoassay tests usually have high specificity 
and are fast and easy to use, but do not permit identification to species level. Another disadvantage of this method is that the presence of a low number of listeria cells in a sample can give rise to a false positive [53]. Various variants of immunoassays are available, including sandwich-type enzyme-linked immunosorbent assay (S-ELISA) [54], nanoparticle immunoassay [55], and enzyme-linked fluorescent assay (ELFA) [56].

\subsection{PCR-related methods}

PCR-based techniques involve the amplification of a specific gene segment of L. monocytogenes such as HlyA-, Iap-, PrfA and SsrA using specific primers followed by monitoring of the amplified segment using agarose gel electrophoresis or other detection techniques such as SYBR Green [57]. Similarly, the 16S rRNA genes of L. monocytogenes can be amplified, sequenced, and searched against existing databases for identification [52]. The disadvantage of PCR-based techniques is related to the costs associated with the purchase of the instrument and reagent, as well as the expertise required to conduct the experiments [58].

\section{Prevention and control of Listeria monocytogenes in food systems}

The prevention and control of L. monocytogenes in RTE foods is paramount in protecting consumers against listeriosis. In a document entitled "Guidelines on the application of general principles of food hygiene to the control of L. monocytogenes in foods" the World Health Organization has provided guidelines that can be followed to minimize the likelihood of the occurrence of L. monocytogenes in RTE foods. According to the [59], food safety measures need to be carried out at different levels of a food production environment, and must include:

1. Establishing the design and adequacy of a production facility: proper location and layout, and adequate equipment and facilities such as water supply, drainage, toilets, temperature control, storage, and hand washing basins.

2. Control of food safety hazards and implementation of hygiene practices throughout the food production line. Accredited HACCP implementation programme.

3. Establishment of adequate sanitary conditions and maintenance of the production facilities; effective cleaning programmes; pest control and proper waste management; and effective monitoring of cleaning programmes.

4. Ensuring adequate implementation of personal hygiene, health status, personal cleanliness and personal behavior of staff.

5. Ensuring adequate and properly functioning transport facilities; these should be well maintained and fit for purpose.

6. Continuous training of staff working in the food production environment, including refresher training.

While the food industry is taking numerous measures to protect foods from Listeria, consumers of RTE food, especially those belonging to the vulnerable groups, must take suitable 


\begin{tabular}{|c|c|c|}
\hline Vulnerable consumer group & Reason for vulnerability & Recommended preventive food hygiene measures \\
\hline Pregnant women & $\begin{array}{l}\text { Weak immune system due } \\
\text { to hormonal changes }\end{array}$ & $\begin{array}{l}\text { - Wash and dry your hands before and after touching } \\
\text { and preparing ready-to-eat food. }\end{array}$ \\
\hline $\begin{array}{l}\text { Unborn fetuses and newborn } \\
\text { babies }\end{array}$ & $\begin{array}{l}\text { Undeveloped immune } \\
\text { system }\end{array}$ & $\begin{array}{l}\text { Refrigerator food contact surfaces should be clean } \\
\text { and sanitized regularly, and operate below } 5^{\circ} \mathrm{C} \text {. }\end{array}$ \\
\hline People over the age of 65 & $\begin{array}{l}\text { Weak immune system due } \\
\text { to ageing }\end{array}$ & $\begin{array}{l}\text { Kitchen utensils such as knives, cutting boards and } \\
\text { graters must be washed before and after being used } \\
\text { in preparing ready-to-eat foods. }\end{array}$ \\
\hline $\begin{array}{l}\text { People with diseases such } \\
\text { as cancer, leukemia, AIDS, } \\
\text { diabetes, or liver or kidney } \\
\text { disease }\end{array}$ & $\begin{array}{l}\text { Weak immune system due } \\
\text { to disease }\end{array}$ & $\begin{array}{l}\text { Minimally processed fruits and vegetables must } \\
\text { be washed thoroughly in flowing water prior to } \\
\text { consumption. }\end{array}$ \\
\hline $\begin{array}{l}\text { People on drugs that can } \\
\text { suppress the immune system } \\
\text { such prednisone or cortisone }\end{array}$ & $\begin{array}{l}\text { Suppressed immune system } \\
\text { due to drugs }\end{array}$ & $\begin{array}{l}\text { - Store raw meat separately from and below cooked } \\
\text { and ready-to-eat food in the refrigerator. } \\
\text { - Protein-rich foods containing meat, fish, chicken, } \\
\text { egg, sprouts and dairy foods that have cooled to }\end{array}$ \\
\hline $\begin{array}{l}\text { People undergoing organ } \\
\text { transplant }\end{array}$ & $\begin{array}{l}\text { Suppressed immune system } \\
\text { due to drug administration }\end{array}$ & $\begin{array}{l}\text { room temperature must be discarded. } \\
\text { Protein-rich foods must be kept either hot }\left(60^{\circ} \mathrm{C} \text { or }\right. \\
\text { hotter }) \text { or cold }\left(5^{\circ} \mathrm{C} \text { or colder). }\right.\end{array}$ \\
\hline
\end{tabular}

Table 3. Listeria in food: Advice to people vulnerable to listeriosis [75].

precautions during the handling of food in their households to prevent the growth and contamination of food by L. monocytogenes (Table 3).

\section{Consumer awareness of listeriosis}

Continuous provision of food safety education to consumers through various channels such as social media increases consumer awareness of the need for safer food handling practices such as hand washing and safe storage of RTE food [60]. The food standard agency of the UK has identified and targeted consumers who are at risk of contracting listeriosis. Vulnerable people, many of whom live and obtain their food independently include those with various forms of cancer, diabetes, alcoholism and diseases of the kidneys, liver, cardiovascular system (e.g., heart disease), digestive system (e.g., Crohn's disease) and musculoskeletal/connective tissue system (e.g., lupus) [61]. Even though most consumers of food sold by street vendors may not have confidence in the safety of RTE foods sold on the street, this often does not affect their preference for such foods because of their affordability, availability and convenience [28].

\section{Conclusions}

RTE foods have gained considerable popularity in many developing and developed countries because of their perceived better flavor, affordability and convenience. Consumers will continue to consume RTE foods despite their association with L. monocytogenes outbreaks. While 
most food processing industries are taking measures to protect foods from listeria, consumers of RTE food, especially those belonging to vulnerable groups, must take suitable precautions during the handling of food to prevent the growth of L. monocytogenes and contamination of food by this organism. Continuous identification of those groups of consumers vulnerable to listeriosis and food safety education directed at them specifically will increase their awareness of the need for safer food handling practices such as hand washing and safe storage of RTE food in an effort to prevent listeriosis.

\section{Acknowledgements}

I would like to acknowledge my wife, Wendy Tabit, for reading this manuscript and making suggestions.

\section{Conflict of interest}

I declare that I have no conflict of interest regarding the publication of this research chapter.

\section{Author details}

Frederick Tawi Tabit

Address all correspondence to: tabitft@uinisa.ac.za

University of South Africa, Johannesburg, South Africa

\section{References}

[1] Madden RH, Hutchison M, Jordan k, Pennone V, Gundogdu O, Corcionivoschi N. Prevalence and persistence of Listeria monocytogenes in premises and products of small food business operators in Northern Ireland. Food Control. 2018;87:70-78

[2] Centre for Disease Control and Prevention (CDC). Listeria (listeriosis): Multistate Outbreak of Listeriosis Linked to Soft Raw Milk Cheese Made by Vulto Creamery (Final Update) [Internet]. 2017. Available from: https://www.cdc.gov/listeria/outbreaks/softcheese-03-17/index.html [Accessed: February 12, 2018]

[3] Roberts AJ, Wiedmann M. Pathogen, host and environmental factors contributing to the pathogenesis of listeriosis. Cellular and Molecular Life Sciences. 2003;60(5):904-918

[4] Beno SM, Stasiewicz MJ, Andrus AD, Ralyea RD, Kent DJ, Martin NH, Wiedmann M, Boor KJ. Development and validation of pathogen environmental monitoring programs for small cheese processing facilities. Journal of Food Protection. 2016;79(12):2095-2106 
[5] Leong D, NicAogáin K, Luque-Sastre L, McManamon O, Hunt K, Alvarez-Ordóñez A, Scollard O, Schmalenberger A, Fanning S, O'Byrne C, Jordan K. A 3-year multi-food study of the presence and persistence of Listeria monocytogenes in 54 small food businesses in Ireland. International Journal of Food Microbiology. 2017;249:18-26

[6] Ryan S, Hill C, Gahan CGM. Acid stress responses in Listeria monocytogenes. Advances in Applied Microbiology. 2008;65:67-91

[7] Oliveira MAD, Maciel de Souza V, Morato Bergamini AM, De Martinis ECP. Microbiological quality of ready-to-eat minimally processed vegetables consumed in Brazil. Food Control. 2011;22(8):1400-1403

[8] Gleeson E, O'Beirne D. Effects of process severity on survival and growth of Escherichia coli and Listeria innocua on minimally processed vegetables. Food Control. 2005;16(8): 677-685

[9] Kocot AM, Olszewska MA. Biofilm formation and microscopic analysis of biofilms formed by Listeria monocytogenes in a food-processing context. LWT - Food Science and Technology. 2017;84:47-57

[10] Li R, Du W, Yang J, Liu Z, Yousef AE. Control of Listeria monocytogenes biofilm by paenibacterin, a natural antimicrobial lipopeptide. Food Control. 2018;84:529-535

[11] Drevets DA, Jelinek TA, Freitag NE. Listeria monocytogenes-infected phagocytes can initiate central nervous system infection in mice. Applied and Environmental Microbiology. 2001;69(3):1344-1350

[12] Quinlan JJ. Foodborne illness incidence rates and food safety risks for populations of low socioeconomic status and minority race/ethnicity: A review of the literature. International Journal of Environmental Research Public Health. 2013;10:3634-3652

[13] Scallan E, Hoekstra RM, Angulo FJ, Tauxe RV, Widdowson M-A, Roy SL, Jones JL, Griffin PM. Foodborne illness acquired in the United States - Major pathogens. Emerging Infectious Diseases. 2011;17(1):7-15

[14] Mensah P, Mwamakamba L, Mohammed C, Nsuemilang D. Public health and food safety in the WHO African region. African Journal of Food, Agriculture, Nutrition, and Development. 2012;12(4):6317-6335

[15] Norton DM, Braden CR. Foodborne listeriosis. In: Ryser EH, Marth EH, editors. Listeria, Listeriosis and Food Safety. 3rd ed. Boca Raton: CRC Press Taylor \& Francis Group; 2007. pp. 305-356

[16] Mylonakis E, Paliou M, Hohmann EL, Calderwood SB, Wing EJ. Listeriosis during pregnancy: A case series and review of 222 cases. Medicine (Baltimore). 2002;81:260-269

[17] McNeill C, Sisson W, Jarrett A. Listeriosis: A resurfacing menace. The Journal for Nurse Practitioners. 2017;13(10):647-654

[18] Scharff LR. Economic burden from health losses due to foodborne illnesses in the United States. Journal of Food Protection. 2012;75(1):123-131 
[19] Thomas MK, Vriezen R, Farber JM, Currie A, Schlech W, Fazil A. Economic cost of a Listeria monocytogenes outbreak in Canada, 2008. Foodborne Pathogens and Disease. 2015;12(12):966-971

[20] Hamon M, Bierne H, Cossart P. Listeria monocytogenes: A multifaceted model. Nature Reviews Microbiology. 2006;4(6):423-434

[21] Gebretsadik S, Kassa T, Alemayehu H, Huruy K, Kebede N. Isolation and characterization of Listeria monocytogenes and other Listeria species in foods of animal origin in Addis Ababa, Ethiopia. Journal of Infection and Public Health. 2011;4(1):22-29

[22] Dowe MJ, Jackson ED, Mori JG, Bell CR. Listeria monocytogenes survival in soil and incidence in agricultural soils. Journal of Food Protection. 1997;60:1201-1207

[23] Gandhi M, Chikindas M. Review: Listeria: A foodborne pathogen that knows how to survive. International Journal of Food Microbiology. 2007;113:1-15

[24] Borucki MK, Peppin JD, White D, Loge F, Call DR. Variation in biofilm formation among strains of Listeria monocytogenes. Applied and Environmental Microbiology. 2003;69: 7336-7342

[25] Misiou O, van Nassau TJ, Lenz CA, Vogel RF. The preservation of Listeria-critical foods by a combination of endolysin and high hydrostatic pressure. International Journal of Food Microbiology. 2018;266(2):355-362

[26] Berrang ME, Frank JF, Meinersmann RJ. Listeria monocytogenes biofilm formation on silver ion impregnated cutting boards. Food Protection Trends. 2010;30:168-171

[27] Belessi CEA, Gounadaki AS, Psomas AN, Skandamis PN. Efficiency of different sanitation methods on Listeria monocytogenes biofilms formed under various environmental conditions. International Journal of Food Microbiology. 2011;145:S46-S52

[28] Asiegbu CV, LebeloSL, Tabit FT. The food safety knowledge and microbial hazards awareness of consumers of ready-to-eat street-vended food. Food Control. 2016;60:422-429

[29] Lokerese RFA, Maslowska-Corker KA, van de Wardt LC, Wijtzes T. Growth capacity of Listeria monocytogenes in ingredients of ready-to-eat salads. Food Control. 2016;60:338-345

[30] Mika-Krajnik M, Yuk H, Kumar A, Yang Y, Zheng Q, Kim M, Ghate V, Yuan W, Pang $X$. Ensuring food security through enhancing microbiological food safety. Cosmos. 2015;(01):69-87

[31] Little CL, Amar CFL, Awofisayo A, Grant KA. Hospital-acquired listeriosis associated with sandwiches in the UK: A cause for concern. Journal of Hospital Infection. 2012;82(1): 13-18

[32] Lambertz ST, Nilsson C, Brådenmark A, Sylvén S, Johansson A, Jansson LM, Lindblad M. Prevalence and level of Listeria monocytogenes in ready-to-eat foods in Sweden 2010. International Journal of Food Microbiology. 2012;160(1):24-31 
[33] Rodrigues C, de Sá C, de Melo C. An overview of Listeria monocytogenes contamination in ready to eat meat, dairy and fishery foods. Ciência Rural. 2017;47(2):1-8

[34] Sibanyoni JJ. Food safety and quality assurance measures of the national school nutrition programme in Mpumalanga Province, South Africa. [Phd Dissertation]: University of South Africa; 2017

[35] Du X-J, Zhang X, Wang X-Y, Su Y-L, Li P, Wang S. Isolation and characterization of Listeria monocytogenes in Chinese food obtained from the central area of China. Food Control. 2017;74:9-16

[36] StepanovićS, DakićI, MartelA, VaneechoutteM, MorrisonD, ShittuA, JežekP, DecostereA, Devriese LA, Haesebrouck F. A comparative evaluation of phenotypic and molecular methods in the identification of members of the Staphylococcus sciuri group. Systematic and Applied Microbiology. 2005;28(4):353-357

[37] Carpentier B, Cerf O. Review-persistence of Listeria monocytogenes in food industry equipment and premises. International Journal of Food Microbiology. 2011;145:1-8

[38] Aureli P, Fiorucci GC, Caroli D, Marchiaro G, Novara O, Leone L, Salmaso S. An outbreak of febrile gastroenteritis associated with corn contaminated by Listeria monocytogenes. New England Journal of Medicine. 2000;342(17):1236-1241

[39] Di Bonaventura G, Piccolomini R, Paludi D, D'Orio V, Vergara A, Conter M, Ianieri A. Influence of temperature on biofilm formation by Listeria monocytogenes on various foodcontact surfaces: Relationship with motility and cell surface hydrophobicity. Journal of Applied Microbiology. 2008;104(6):1552-1561

[40] Lourenço A, Rego F, Brito L, FrankJF. Evaluation of methods to assess the biofilm-forming ability of Listeria monocytogenes. Journal of Food Protection. 2012;75(80):1411-1417

[41] Blackman IC, Frank JF. Growth of Listeria monocytogenes as a biofilm on various foodprocessing surfaces. Journal of Food Protection. 1996;59(8):827-831

[42] Catellani P, Scapin RM, Alberghini L, Radu IL, Giaccone V. Levels of microbial contamination of domestic refrigerators in Italy. Food Control. 2014;42:257-262

[43] Evans EW, Redmond EC. Analysis of older adults' domestic kitchen storage practices in the United Kingdom: Identification of risk factors associated with Listeriosis. Journal of Food Protection. 2015;78(4):738-745

[44] Beumer RR, Te Giffel MC, Spoorenberg E, Rombouts FM. Listeria species in domestic environments. Epidemiology and Infection. 1996;117(3):437-442

[45] Azevedo I, Regalo M, Mena C, Cameiro L, Teixera P, Hogg T, Gibbs PA. Incidence of Listeria spp. in domestic refrigerators in Portugal. Food Control. 2005;16(2):121-124

[46] Luber P. The codex Alimentarius guidelines on the application of general principles of food hygiene to the control of Listeria monocytogenes in ready-to-eat foods. Food Control. 2011;22(9):1482-1483 
[47] Nørrung B. Microbiological criteria for Listeria monocytogenes in foods under special consideration of risk assessment approaches. International Journal of Food Microbiology. 2000;62(3):217-221

[48] Food Standards Australia-New Zealand (FSANZ). Criteria for Listeria monocytogenes Microbiological Limits for Foods [Internet]. 2014. Available from: http://www.foodstandards.gov.au/code/proposals/Documents/P1017-MicroAppR-SD2.pdf [Accessed: February 12, 2018]

[49] Food Safety Authority of Ireland: Listeria monocytogenes. Microbial factsheet series Issue No 1 September 2011 [Internet]. 2016. Available from: https://www.fsai.ie/listeriamonocytogenes.html [Accessed: February 13, 2018]

[50] Rosimin AA, Kim M-J, Joo I-S, Suh S-H, Kim KS. Simultaneous detection of pathogenic Listeria including atypical Listeria innocua in vegetables by a quadruplex PCR method. LWT - Food Science and Technology. 2016;69:601-607

[51] Dwivedi HP, Jaykus L. Detection of pathogens in foods: The current state-of-the-art and future directions. Critical Reviews in Microbiology. 2011;37(1):40-63

[52] Liu H, Lu L, Pan Y, Sun X, Hwang C-A, Zhao Y, Wu VCH. Rapid detection and differentiation of Listeria monocytogenes and Listeria species in deli meats by a new multiplex PCR method. Food Control. 2015;52:78-84

[53] Capita R, Alonso-Calleja C, Moreno B. García-Fernández MC: Occurrence of Listeria species in retail poultry meat and comparison of a cultural/immunoassay for their detection. International Journal of Food Microbiology. 2001;65(1-2):75-82

[54] Liu A, Xiong Q, Shen L, Li W, Zeng Z, Li C, Liu S, Liu Y, Han G. A sandwich-type ELISA for the detection of Listeria monocytogenes using the well-oriented single chain Fv antibody fragment. Food Control. 2017;79:156-161

[55] Jaakohuhta S, Härmä H, Tuomola M, Lövgren T. Sensitive Listeria spp. immunoassay based on europium(III) nanoparticulate labels using time-resolved fluorescence. International Journal of Food Microbiology. 2007;114(3):288-294

[56] Sewell AM, Warburton DW, Boville A, Daley EF, Mullen K. The development of an efficient and rapid enzyme linked fluorescent assay method for the detection of Listeria spp. from foods. International Journal of Food Microbiology. 2003;81(2):123-129

[57] Cheng J-Q, Healey S, Regan P, Laksanalamai P, Hu Z. PCR-based methodologies for detection and characterization of Listeria monocytogenes and Listeria ivanovii in foods and environmental sources. Food Science and Human Wellness. 2017;6(2):39-59

[58] Tabit FT. Advantages and limitations of potential methods for the analysis of bacteria in milk: A review. Journal of Food Science and Technology. 2016;53(1):42-49

[59] Codex Alimentarius: Guidelines on the application of general principles of food hygiene to the control of Listeria monocytogenes in foods, CAC/GL 61-2007 [Internet]. 2007. Available from: http://www.fao.org/input/download/standards/10740/CXG_061e.pdf [Accessed: February 12, 2018] 
[60] Lin C-TJ, Jensen KL, Yen ST. Awareness of foodborne pathogens among US consumers. Food Quality and Preference. 2005;16(5):401-412

[61] Food Standard Agency (FSA): Listeria guidance for healthcare and social care organisations [Internet]. 2016. Available from: https://www.food.gov.uk/sites/default/files/listeriaguidance-june2016-rev.pdf [Accessed: February 14, 2018]

[62] CDCa. Listeria (listeriosis): Multistate Outbreak of Listeriosis Linked to Frozen Vegetables (Final Update) [Internet]. 2016. Available from: https://www.cdc.gov/listeria/outbreaks/ frozen-vegetables-05-16/index.html [Accessed: February 12, 2018]

[63] CDCb. Listeria (listeriosis): Multistate Outbreak of Listeriosis Linked to Raw Milk Produced by Miller's Organic Farm in Pennsylvania (Final Update) [Internet]. 2016. https:// www.cdc.gov/listeria/outbreaks/raw-milk-03-16/index.html [Accessed: February 12, 2018]

[64] CDCc. Listeria (listeriosis): Multistate Outbreak of Listeriosis Linked to Packaged Salads Produced at Springfield, Ohio Dole Processing Facility (Final Update) [Internet]. 2016. Available from: https://www.cdc.gov/listeria/outbreaks/bagged-salads-01-16/index.html [Accessed: February 12, 2018]

[65] CDCa. Listeria (listeriosis): Multistate Outbreak of Listeriosis Linked to Soft Cheeses Distributed by Karoun Dairies, Inc. (Final Update) [Internet]. 2015. Availlable from: https:// www.cdc.gov/listeria/outbreaks/soft-cheeses-09-15/index.html [Accessed: February 12, 2018]

[66] CDCb. Listeria (listeriosis): Multistate Outbreak of Listeriosis Linked to Blue Bell Creameries Products (Final Update) [Internet]. 2015. Available from: https://www.cdc. gov/listeria/outbreaks/ice-cream-03-15/index.html [Accessed: February 12, 2018]

[67] CDCa. Listeria (listeriosis): Multistate Outbreak of Listeriosis Linked to Commercially Produced, Prepackaged Caramel Apples Made from Bidart Bros. Apples (Final Update) [Internet]. 2014. Available from: https://www.cdc.gov/listeria/outbreaks/caramelapples-12-14/index.html [Accessed: February 12, 2018]

[68] CDCb. Listeria (listeriosis): Wholesome Soy Products, Inc. Sprouts and Investigation of Human Listeriosis Cases (Final Update) [Internet]. 2014. Available from: https://www. cdc.gov/listeria/outbreaks/bean-sprouts-11-14/index.html [Accessed: February 12, 2018]

[69] CDCc. Listeria (listeriosis): Oasis Brands, Inc. Cheese Recalls and Investigation of Human Listeriosis Cases (Final Update) [Internet]. 2014. Available from: https://www.cdc.gov/ listeria/outbreaks/cheese-10-14/index.html [Accessed: February 12, 2018]

[70] CDCd. Listeria (listeriosis): Multistate Outbreak of Listeriosis Linked to Roos Foods Dairy Products (Final Update) [Internet] 2014. Available from: https://www.cdc.gov/listeria/outbreaks/cheese-02-14/index.html [Accessed: February 12, 2018]

[71] National Institute of Communicable Diseases, (NICD): Situation report on listeriosis outbreak, South Africa, 2017 [Internet]. 2017. Available from: http://www.nicd.ac.za/ wp-content/uploads/2017/12/NICD_Situation_report_on_listeriosis_outbreak_South_ Africa_04_December_2017.pdf [Accessed: February 16, 2018] 
[72] Herald Sun: One dead in Victorian listeria food poisoning surge [Internet]. 2017. Available from: http://www.heraldsun.com.au/news/victoria/one-victorian-dead-in-listeriafood-poisoning-surge/news-story/16ca34ccf916371d3b05695df8b296ec [Accessed: February $17,2018]$

[73] European Centre for Disease Prevention and Control (ECDC): Annual Epidemiological Report 2016 - Listeriosis. Stockholm: ECDC; 2016. [Internet]. 2016. Available from: http:// ecdc.europa.eu/sites/portal/files/documents/Listeriosis\%20-\%20Annual\%20epidemiological\%20report_0.pdf [Accessed: February 15, 2018]

[74] Hamidiyan N, Salehi-Abargouei A, Rezaei Z, Tafti RD, Akrami-Mohajeria F. The prevalence of Listeria spp. food contamination in Iran: A systematic review and meta-analysis. Food Research International. DOI: 10.1016/j.foodres.2018.02.038

[75] Food Standards Australia-New Zealand (FSANZ): Listeria and food - advice for people at risk [Online]. 2018. Available from: http://www.foodstandards.gov.au/consumer/ safety/listeria/documents/listeria-1.pdf [Accessed: February 15, 2018] 
